\title{
Commentary
}

\section{Mitochondria-Targeted Antioxidants as Promising Drugs for Treatment of Age-Related Brain Diseases}

\author{
Vladimir P. Skulachev* \\ Faculty of Bioengineering and Bioinformatics and A.N. Belozersky Institute of Physico-Chemical Biology, \\ Moscow State University, Moscow, Russia
}

Handling Associate Editor: Alexander Boldyrev

Accepted 5 September 2011

\begin{abstract}
Much experimental evidence suggests that age-related brain pathologies are most often mediated by reactive oxygen species primarily originating from mitochondria (mROS). Two papers with such evidence have been recently published in the Journal of Alzheimer's Disease (Stefanova et al., J Alzheimers Dis 21, 476-491, 2010; Lloret et al., J Alzheimers Dis, doi: 10.3233/JAD-2011-110890). In the first paper, it was shown that appearance of a typical behavioral trait of aging in rats (that old animals do not enter an open arm in a maze) was completely reversed by ten weeks treatment of the old rats with the mitochondria-targeted antioxidant SkQ1. In the second article, the authors identified molecular mechanisms by which amyloid$\beta$-induced mROS can mediate hyperphosphorylation of the tau protein, a key event in Alzheimer's disease. Conventional antioxidants prevented such hyperphosphorylation. In this article, I will summarize the present state of the art in this field. I conclude that mitochondria-targeted rechargeable antioxidants are promising as tools to treat brain pathologies developing in elderly humans.
\end{abstract}

Keywords: Alzheimer's disease, behavior, hippocampus, mitochondria-targeted antioxidant, plastoquinone, stroke

There is general agreement among gerontologists that oxidative stress gradually increases as organisms age. This can be a consequence of (i) stimulation with age of production of reaction oxygen species (ROS); (ii) decrease in quenching of ROS; (iii) both of these factors; or (iv) simply duration of life-long exposure of an aging organism to endogenous ROS. Any of these effects can, in turn, be a result of occasional damage to organismal regulatory systems or require

\footnotetext{
*Correspondence to: Vladimir P. Skulachev, Faculty of Bioengineering and Bioinformatics and A.N. Belozersky Institute of Physico-Chemical Biology, Moscow State University, Vorobyevy Gory 1, Moscow 119991, Russia. Tel.: +7 49593955 30; Fax: +7 49593903 38; E-mail: skulach@belozersky.msu.ru.
}

activation of a special aging program (or inactivation of a "youth" program) representing the final step of ontogenesis (for details, see [1-3]). ROS generated on the outer surface of the cell membrane are mainly produced by a special superoxide $\left(\mathrm{O}_{2}^{-\bullet}\right)$-forming enzyme (NADPH oxidase). Of those generated inside the cell, they are assumed to be often a result of a leakage of electrons transported by the mitochondrial respiratory chain when $\mathrm{O}_{2}{ }^{-\bullet}$ is formed by initial or middle spans of the chain instead of $\mathrm{H}_{2} \mathrm{O}$ formation by its terminal enzyme, cytochrome oxidase [2,3]. If this is the case, aging might be slowed by treatment with antioxidants quenching $\mathrm{O}_{2}^{-\bullet}$ and other ROS. Unfortunately, ROS normally perform several physiological functions 
of vital importance, and their total elimination entails death of the organism. For example, mice and rats kept in a chamber with $\mathrm{O}_{2}{ }^{-\bullet}$-free air die within three weeks [5]. Thus, the goal is to specifically lower only those ROS that are involved in aging processes. If it really is mitochondrial ROS (mROS) that promote the aging process, there is a chance to decelerate aging by moderate doses of mitochondria-targeted antioxidants that would not dramatically affect extra-mitochondrial ROS operating in the cytosol as secondary messengers of some physiological signals, or outside the cell as killers of microorganisms invading damaged tissues. In our group, mitochondria-targeted antioxidants [plastoquinonyl decyltriphenylphosphonium (SkQ1) and plastoquinonyl decylrhodamine 19 (SkQR1)] have been synthesized [6]. We found that these membranepenetrating cations are specifically accumulated in the inner mitochondrial membrane [6] due to the fact that the mitochondrial interior is the only negatively charged compartment in the cell [7]. Further studies revealed that the SkQs prevent peroxidation of cardiolipin in isolated mitochondria and $\mathrm{H}_{2} \mathrm{O}_{2}$-induced apoptosis of human fibroblasts and HeLa cells [8]. It was found that SkQs not only interrupt chain reaction of cardiolipin peroxidation by already formed ROS but, at higher concentrations, they also lower the rate of ROS formation in respiratory chain due to mild uncoupling. Both SkQ1 and SkQR1 proved to be carriers of fatty acid anions, catalyzing in this way $\mathrm{H}^{+}$transport through mitochondrial membrane, mediated by fatty acid cycling [9]. Besides this effect, SkQR1 per se was shown to be cationic protonophorous uncoupler [10]. The SkQ-induced partial uncoupling decreases mitochondrial transmembrane electric potential $(\Delta \Psi)$ and, as a consequence, prevents ROS formation which is very sensitive to a $\Delta \Psi$ lowering [11].

It was shown that SkQ1 treatment prolongs the lifespan of the fungus Podospora anserina, the crustacean Ceriodaphnia, the fly Drosophila, the short-lived fish Nothobranchius furzeri, mice [8, 12], hamsters, and mole-voles (Anisimov VN et al., unpublished). Numerous traits of aging were shown to be delayed, prevented, and in some cases even reversed by SkQs [8-12].

Several effects of SkQs were observed when brain functions were studied. In particular, a single intraperitoneal injection of SkQR1 $(0.5-2 \mu \mathrm{mol} / \mathrm{kg}$ body weight) to rats strongly decreased the infarct volume in brain and related behavioral defect (performance in the limb placement test) caused by transient occlusion of the middle cerebral artery (Fig. 1). These data were obtained by Zorov and coworkers in our group in Moscow $[13,14]$. A demonstrative effect of
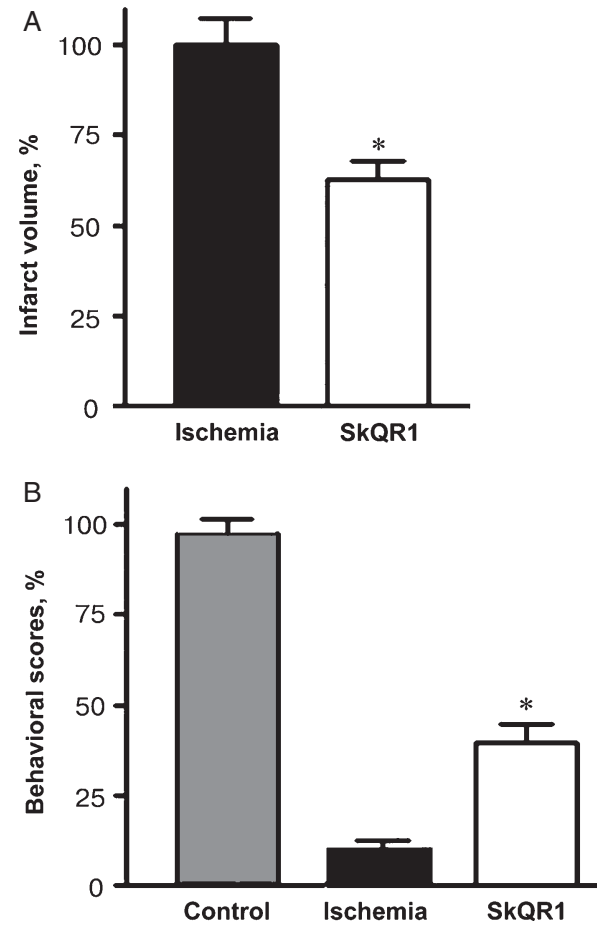

Fig. 1. SkQR1 lowers brain infarct volume as well as damage to the performance of the limb placement test in rats after transient middle cerebral artery occlusion. Where indicated, $1 \mu \mathrm{mol} \mathrm{SkQR1}$ per kg of body weight was injected intraperitoneally $24 \mathrm{~h}$ before the $60 \mathrm{~min}$ occlusion of the artery. The ischemia effect was studied $24 \mathrm{~h}$ after the occlusion. *, here and below, $p<0.05$ for SkQ effect. Reprinted from Plotnikov et al. [13], with permission.

in vivo treatment with SkQ1 was observed in Kolosova's group in Novosibirsk, where agedependent behavioral effects were studied in Wistar rats [15]. Rats of 3- and 14-month age were investigated. An elevated plus maze with two open and two closed arms was used. Young animals placed in the maze center entered both types of arms with equal probability. However, the 14-month-old rats preferred to enter the closed arms only, the probability of entering the open arms being extremely low. If, nevertheless, a 14-month-old rat entered an open arm, the animal immediately left this arm. Addition of very small amount of SkQ1 to the food $(250 \mathrm{nmol} / \mathrm{kg}$ body weight daily) for 10 weeks completely reversed the age effect. With SkQ1, the probability of entering an open arm for the 14-month-old rats was as high as for young rats and, when entering an open arm, the SkQ1-treated old rats spent in it a time which was almost as long as for the young rodents (Fig. 2). Number of squares crossed by the animals in the open field test proved to be slightly (by 25\%) smaller in the 14-month-old rats than for the 3-month-old animals. This difference was also 

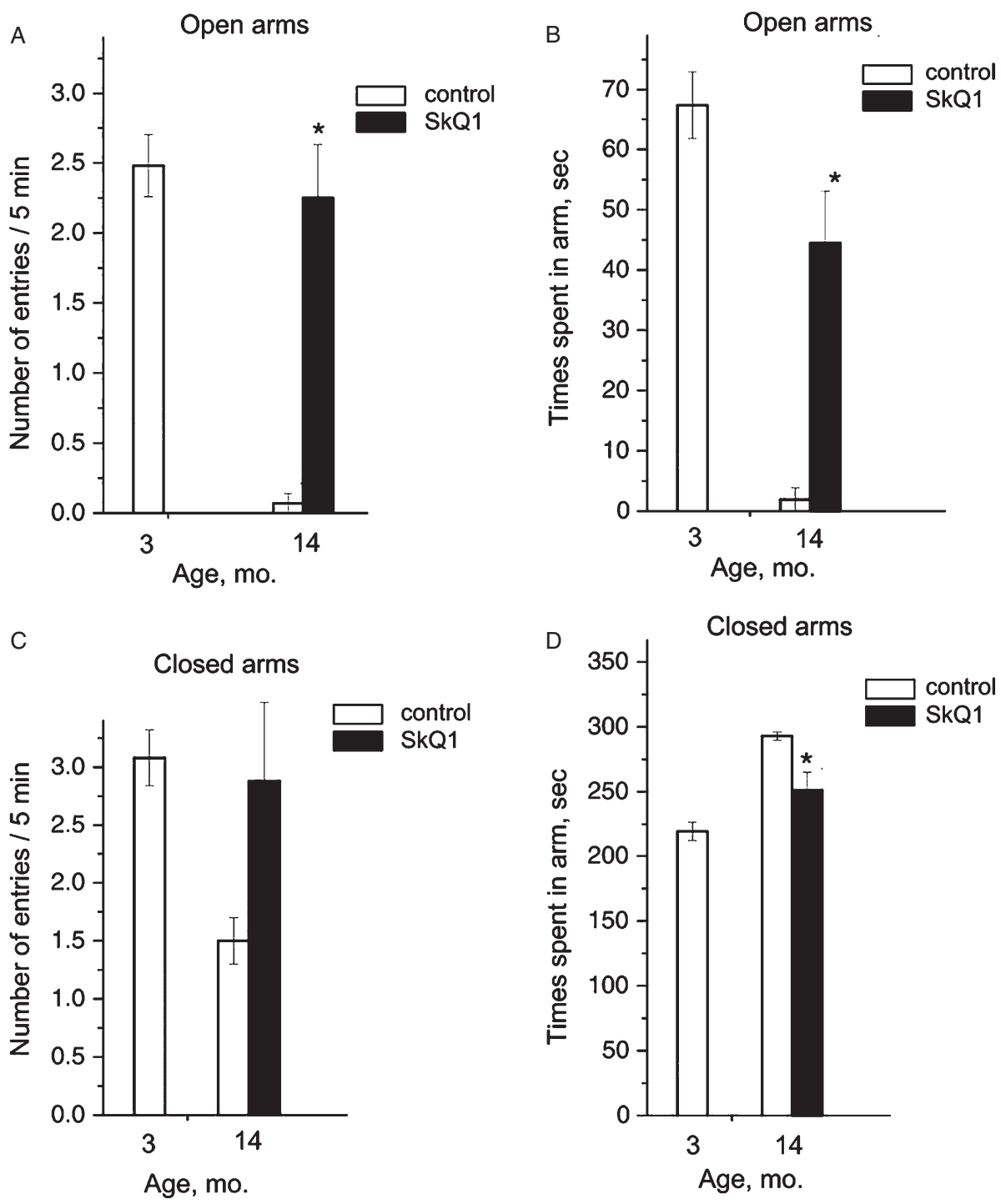

Fig. 2. SkQ1 reverses age-dependent behavioral defects in Wistar rats. The elevated plus maze was used. Where indicated, SkQ1 (250 nmol /kg body weight daily) was added to the food of old rats during the final 10 weeks. Reprinted from Stefanova et al. [15], with permission from IOS Press.

abolished by SkQ1. Rearings in the maze or the open field and head dips in the maze were age-independent and SkQ1-insensitive [15].

There is only one treatment which prolongs life of many species and delays development of numerous traits of aging as does SkQs. This is calorie restriction. Our explanation for this similarity is that both SkQs and calorie restriction interrupt execution of the aging program. Among the traits in question, there is behavior of an animal during the final week(s) of life. As mentioned by Dr. Arlan A. Richardson of San Antonio, "calorie restriction minimizes the period in which an animal is morbid, sitting around its cage, waiting to meet its maker" (cited after [16]). As shown by Shabalina et al. in Stockholm and Anisimov et al. in St. Petersburg (unpublished), this effect is not observed when mice receive SkQ1 with drinking water throughout their lives. The animals are mobile and active as long as they are alive. Notably, SkQ1 did not affect the food consumption by the animals (Anisimov VN et al. and Shabalina IG et al., unpublished).

It is well established that one of the key events in the development of Alzheimer's disease (AD) is the release of amyloid- $\beta$ peptide $(A \beta)$ from its protein 
precursor (AßPP) (for review, see [4]). It is also clear that impairment of synaptic plasticity occurs before apoptotic and neurodegenerative events typical for the terminal stage of AD. It correlates with accumulation of $A \beta$, causing the synaptic dysfunction and loss of memory accompanying AD [17-19]. As a model of cell memory, an electric response of a hippocampal slice (long-term potentiation, LTP) is used [20]. Quite recently, Kapay and coworkers from our and Dr. V.G. Skrebitsky's groups in Moscow performed a direct experiment on prevention of $A \beta$ toxicity in hippocampus by in vivo treatment of rats with $1 \mu \mathrm{mol}$ SkQR1 per kg of body weight. The compound was injected intraperitoneally into the animal $24 \mathrm{~h}$ before hippocampal slices were obtained to measure long-term potentiation (LTP). Some slices were pretreated with $\mathrm{A} \beta$ for $15 \mathrm{~min}$. As is seen in Fig. 3, A $\beta$ impaired LTP. Treatment of the animal with SkQR1 prevented such impairment [21]. When this paper was in preparation, a publication by Ma et al. [22] appeared where another penetrating mitochondria-targeted cationic antioxidant, MitoQ, was used to prevent the effect of $A \beta$ on LTP. To this end, however, the antioxidant was added in vitro, i.e., directly on the hippocampal slice. Consistent with our observation with the in vivo antioxidant treatment, the in vitro addition of $0.5 \mu \mathrm{M}$ MitoQ prevented the $A \beta$-induced impairment of LTP. A similar effect was produced by adding a superoxide dismutase and the catalase mimetic EUK134 as well as by hyperproduction of mitochondrial superoxide dismutase. LTP damage could also be observed in A $\beta P P / P S 1$ AD mutant mice. In this case, LTP could also be normalized by in vitro MitoQ [22] ${ }^{1}$. The authors did not try MitoQ in vivo, where a narrow concentration window between anti- and prooxidant effects, inherent to this quinone derivate, may create problems. Just this property of MitoQ introduced by Murphy and Smith before SkQs were tested [24] might be the reason why clinical trials of MitoQ were without positive results in the case of Parkinson's disease [24, 25] and Friedrich's ataxia [26]. For SkQs, the beneficial concentration window is as wide as about 1,000 , a fact which should strongly increase the likelihood of success of in vivo treatments $[6,8]$.

Another important observation was reported by Ma and colleagues [22]. They showed that addition of $A \beta$ to hippocampal slices greatly increased the mROS level, and MitoQ in vitro or hyperproduction of mitochondrial superoxide dismutase in vivo abolished this

\footnotetext{
${ }^{1}$ For prevention by added MitoQ of inhibiting in vitro action of $\mathrm{A} \beta$, see ref. [23].
}
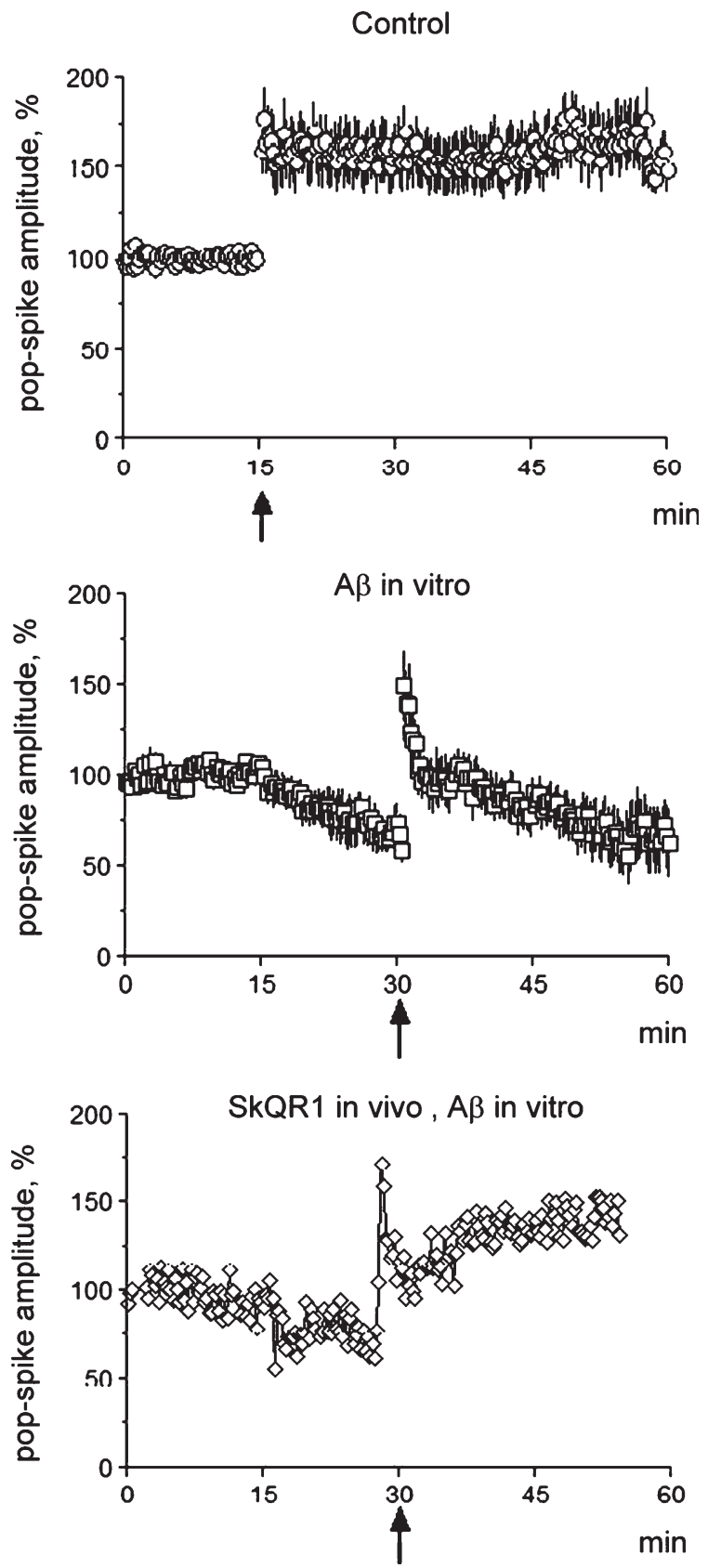

Fig. 3. SkQR1 treatment in vivo prevents decay of the long-term potentiation (LTP) caused by in vitro addition of $A \beta$ to a hippocampal slice. For the SkQR1 treatment, see Fig. 2. A $\beta$ was added 15 min before the LTP induction with high-frequency electric stimulation (arrow). Reprinted from Kapay et al. [21], with permission.

increase. There are numerous facts indicating that $\mathrm{A} \beta$ initiates ROS production in vitro and in vivo $[4$, $22,27-35]$, and these ROS primarily originate from mitochondria [4, 26, 39-42]. It was also found that $\mathrm{A} \beta$ accumulates in the mitochondrial matrix, being 
transported through the outer and the inner mitochondrial membrane by the TOM and TIM complexes, respectively [4, 35, 39-43]. Inside mitochondria, $\mathrm{A} \beta$ inhibits cytochrome oxidase, pyruvate and $\alpha$ ketoglutarate dehydrogenases, ATP/ADP antiporter, presequence peptidase and some other enzyme complexes, entailing a decrease in respiration, mitochondrial membrane potential and respiratory ATP synthesis $[4,35]$. As a result, respiratory chain-linked mROS production strongly increases, causing synaptic failure and, later, apoptosis of brain cells [4, 35, 36].

Toxicity of $A \beta$ added to brain mitochondria isolated from young males was much higher than from young females, the latter being rather resistant to $A \beta$. The resistance disappeared with age. This interesting observation was made by Viña and his colleagues from Valencia [44]. Quite recently, his group identified a chain of AD-inherent events occurring downstream from mROS. They showed that ROS somehow upregulate expression of the regulator of Calcineurin gene, RCAN1. RCAN1 protein inhibits the ability of calcineurin to operate as a phosphatase of tau-protein. As a result, tau-protein is hyperphosphorylated by glycogen synthase kinase- $3 \beta$ (GSK3 $\beta$ ), a tau-kinase. This effect is stimulated by an RCAN1-induced increase in tau-kinase activity of GSK3 $\beta$. Hyperphosphorylation of tau protein leads to formation of neurofibrillary tangles, thus causing synaptic failure and apoptosis (Fig. 4; for reviews, see [4, 35]). Viña and his

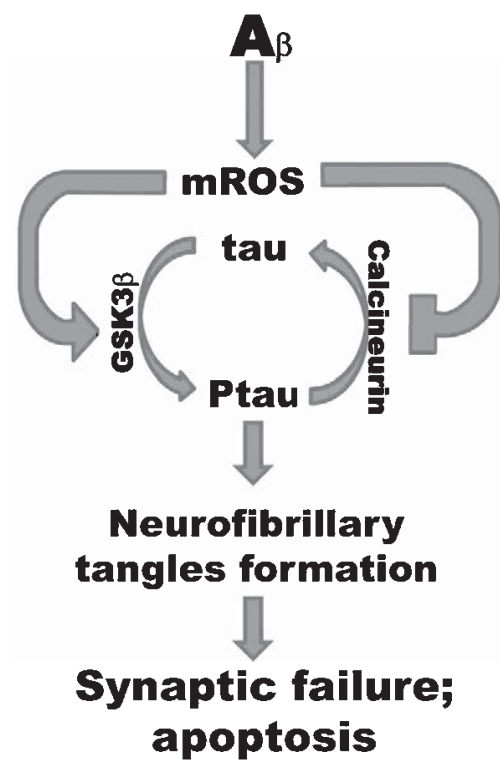

Fig. 4. Tentative scheme illustrating how mitochondrial reactive oxygen species (mROS) mediate the $A \beta$-induced damage to $A D$ neurons. For details, see the text and ref. [45]. colleagues studied fetal rat cortical neurons and succeeded in interrupting the $\mathrm{A} \beta$-induced damage by in vitro addition of high $(1 \mathrm{mM})$ concentrations of watersoluble antioxidants, i.e., Trolox and GSH-mono ethyl ester [45]. In experiments of Ma et al. on hippocampal slices, 0.5 $\mu \mathrm{M}$ MitoQ, a mitochondria-targeted antioxidant, was used for this purpose. In our experiments on the same system, we employed in vivo treatment of rats with $1 \mu \mathrm{mol} \mathrm{SkQR} 1 / \mathrm{kg}$ body weight, a more potent antioxidant addressed to mitochondria. Its effective concentration should be much lower than that of the in vitro added MitoQ. As shown by direct measurement of pharmacokinetics of SkQ1 in rats, its level in brain was lower than in some other tissues [12]. Such high efficiency of SkQs can be explained by a combination of the following factors:

(1) SkQs are rechargeable antioxidants which are reduced in center $i$ of respiratory chain complex III, localized in the inner leaflet of the inner mitochondrial membrane [12, 46].

(2) SkQs are very effectively concentrated in this mitochondrial membrane leaflet. In cytosol, [SkQ] must be about 10-fold higher than in the solution outside the cell due to electrophoretic movement of SkQ supported by $\Delta \Psi$ across the outer cell membrane (about $60 \mathrm{mV}$ ). The $\Delta \Psi$ across the inner mitochondrial membrane is about $180 \mathrm{mV}$, which means that [SkQ] in the mitochondrial matrix should be $10^{3}$ higher than in the cytosol. The distribution of SkQ1 in the membrane/water system is about $10^{4}: 1$. Altogether, this should result in SkQ concentration in the inner leaflet of the inner mitochondrial membrane $10^{8}$ times higher than in the extracellular solution [12].

(3) In mitochondria, SkQ combines which cardiolipin, the mitochondria-specific phospholipid which is first of all attacked by mROS initiating a chain reaction of lipid peroxidation in the inner membrane of mitochondria $[12,46]$.

These unique properties of mitochondria-targeted rechargeable antioxidants make them promising in treatment of $\mathrm{AD}$ and other mROS-mediated brain pathologies. Notably, non-targeted antioxidants ( $\alpha$-tocopherol, ascorbate, and $\alpha$-lipoate) proved to be safe but ineffective in treating AD patients [47]. This is hardly surprising since these antioxidants are not only non-specific to the intracellular compartments but also are not rechargeable and, hence, much less efficient than SkQ. The latter is also true for mitochondriatargeted $\alpha$-tocopherol. As to mitochondria-targeted antioxidant enzymes, they cannot be applied for in vivo treatment of humans. Elucidation of details of molecular mechanisms of antioxidant SkQ effects and clinical 
trials of these new compounds is now in progress in our and some other groups [48].

\section{DISCLOSURE STATEMENT}

The author's disclosure is available online (http://www.j-alz.com/disclosures/view.php?id=998).

\section{REFERENCES}

[1] Skulachev VP (2003) Aging and the programmed death phenomena. In Topics in Current Genetics, Vol. 3. Nystrom T, Osiewacz HD, Eds. Model systems in ageing. SpringerVerlag, Berlin Heidelberg, pp. 191-238.

[2] Skulachev VP, Longo VD (2005) Aging as a mitochondriamediated atavistic program: Can aging be switched off? Ann N Y Acad Sci 1057, 145-164.

[3] Longo VD, Mitteldorf J, Skulachev VP (2005) Programmed and altruistic ageing. Nat Rev Gene 6, 866-872.

[4] Pagani L, Eckert A (2011) Amyloid-Beta interaction with mitochondria. Int J Alzheimers Dis 2011, 925050.

[5] Goldstein N (2002) Reactive oxygen species as essential components of ambient air. Biochemistry (Mosc) 67, 161-170.

[6] Antonenko YN, Avetisyan AV, Bakeeva LE, Chernyak BV, Chertkov VA, Domnina LV, Ivanova OY, Izyumov DS, Khailova LS, Klishin SS, Korshunova GA, Lyamzaev KG, Muntyan MS, Nepryakhina OK, Pashkovskaya AA, Pletjushkina OY, Pustovidko AV, Roginsky VA, Rokitskaya TI, Ruuge EK, Saprunova VB, Severina II, Simonyan RA, Skulachev IV, Skulachev MV, Sumbatyan NV, Sviryaeva IV, Tashlitsky VN, Vassiliev JM, Vyssokikh MY, Yaguzhinsky LS, Zamyatnin AA Jr, Skulachev VP (2008) Mitochondriatargeted plastoquinone derivatives as tools to interrupt execution of the aging program. 1. Cationic plastoquinone derivatives: Synthesis and in vitro studies. Biochemistry (Mosc) 73, 1273-1287.

[7] Liberman EA, Topaly VP, Tsofina LM, Jasaitis AA, Skulachev VP (1969) Mechanism of coupling of oxidative phosphorylation and the membrane potential of mitochondria. Nature 222, 1076-1078.

[8] Skulachev VP, Anisimov VN, Antonenko YN, Bakeeva LE, Chernyak BV, Erichev VP, Filenko OF, Kalinina NI, Kapelko VI, Kolosova NG, Kopnin BP, Korshunova GA, Lichinitser MR, Obukhova LA, Pasyukova EG, Pisarenko OI, Roginsky VA, Ruuge EK, Senin II, Severina II, Skulachev MV, Spivak IM, Tashlitsky VN, Tkachuk VA, Vyssokikh MY, Yaguzhinsky LS, Zorov DB (2009) An attempt to prevent senescence: A mitochondrial approach. Biochim Biophys Acta 1787, 437461.

[9] Severin FF, Severina II, Antonenko YN, Rokitskaya TI, Cherepanov DA, Mokhova EN, Vyssokikh MY, Pustovidko AV, Markova OV, Yaguzhinsky LS, Korshunova GA, Sumbatyan NV, Skulachev MV, Skulachev VP (2010) Penetrating cation/fatty acid anion pair as a mitochondria-targeted protonophore. Proc Natl Acad Sci U S A 107, 663-668.

[10] Antonenko YN, Avetisyan AV, Cherepanov DA, Knorre DA, Korshunova GA, Markova OV, Ojovan SM, Perevoshchikova IV, Pustovidko AV, Rokitskaya TI, Severina II, Simonyan RA, Smirnova EA, Sobko AA, Sumbatyan NV, Severin FF, Skulachev VP (2011) Derivatives of Rhodamine 19 as mild mitochondria-targeted cationic uncouplers. J Biol Chem 286, 17831-17840.
[11] Korshunov SS, Skulachev VP, Starkov AA (1997) High protonic potential actuates a mechanism of production of reactive oxygen species in mitochondria. FEBS Lett 416, 15-18.

[12] Skulachev MV, Antonenko YN, Anisimov VN, Chernyak BV, Cherepanov DA, Chistyakov VA, Egorov MV, Kolosova NG, Korshunova GA, Lyamzaev KG, Plotnikov EY, Roginsky VA, Savchenko AY, Severina II, Severin FF, Shkurat TP, Tashlitsky VN, Shidlovsky KM, Vyssokikh MY, Zamyatnin AA Jr, Zorov DB, Skulachev VP (2011) Mitochondrialtargeted plastoquinone derivatives. Effect on senescence and acute age-related pathologies. Curr Drug Targets 12, 800826.

[13] Plotnikov EY, Silachev DN, Chupyrkina AA, Danshina MI, Jankauskas SS, Morosanova MA, Stelmashook EV, Vasileva AK, Goryacheva ES, Pirogov YA, Isaev NK, Zorov DB (2010) New-generation Skulachev ions exhibiting nephroprotective and neuroprotective properties. Biochemistry (Mosc) 75, 145150.

[14] Silachev DN, Pevzner IB, Zorova LD, Plotnokov EY, Gulyaev VV, Pirogov YA, Isaev NK, Skulachev VP, Zorov DB (2011) New generation of penetrating cations as potential agents to rescue from ischemic stroke. FEBS J 278(Suppl.1), 280.

[15] Stefanova NA, Fursova AZh, Kolosova NG (2010) Behavioral effects induced by mitochondria-targeted antioxidant SkQ1 in Wistar and senescence-accelerated OXYS rats. J Alzheimers Dis 21, 479-491.

[16] Hopkin K (2003) Dietary drawbacks. Sci Aging Knowledge Environ 8, NS4.

[17] Selkoe DJ (2002) Alzheimer's disease is a synaptic failure. Science 298, 789-791.

[18] Oddo S, Caccamo A, Shepherd JD, Murphy MP, Golde TE, Kayed R, Metherate R, Mattson MP, Akbari Y, LaFerla FM (2003) Triple-transgenic model of Alzheimer's disease with plaques and tangles: Intracellular Abeta and synaptic dysfunction. Neuron 39, 409-421.

[19] Haass C, Selkoe DJ (2007) Soluble protein oligomers in neurodegeneration: Lessons from the Alzheimer's amyloid beta-peptide. Nat Rev Mol Cell Biol 8, 101-112.

[20] Malenka RC, Nicoll RA (1999) Long-term potentiation: A decade of progress? Science 285, 1870-1874.

[21] Kapay NA, Isaev NK, Stelmashook EV, Popova OV, Zorov DB, Skrebitsky VG, Skulachev VP (2011) In vivo injected mitochondriatargeted plastoquinone antioxidant SkQR1 prevents ßamyloidinduced decay of longterm potentiation in rat hippocampal slices. Biochemistry (Mosc) 76, 1695-1699.

[22] Ma T, Hoeffer CA, Wong H, Massaad CA, Zhou P, Iadecola C, Murphy MP, Pautler RG, Klann E (2011) Amyloid $\beta$-induced impairments in hippocampal synaptic plasticity are rescued by decreasing mitochondrial superoxide. J Neurosci 31, 55895595.

[23] Manczak M, Mao P, Calkins MJ, Cornea A, Reddy AP, Murphy MP, Szeto HH, Park B, Reddy PH (2010) Mitochondria-targeted antioxidants protect against amyloidbeta toxicity in Alzheimer's disease neurons. J Alzheimers Dis 20(Suppl 2), S609-631.

[24] Murphy MP, Smith RA (2007) Targeting antioxidants to mitochondria by conjugation to lipophilic cations. Annu Rev Pharmacol Toxicol 47, 629-656.

[25] Snow BJ, Rolfe FL, Lockhart MM, Frampton CM, O'Sullivan JD, Fung V, Smith RA, Murphy MP, Taylor KM, Protect Study, Group (2010) A double-blind, placebo-controlled study to assess the mitochondria-targeted antioxidant MitoQ as a disease-modifying therapy in Parkinson's disease. Mov Disord 25, 1670-1674. 
[26] Tauskela JS (2007) MitoQ-a mitochondria-targeted antioxidant. I Drugs 10, 399-412.

[27] Smith MA, Richey PL, Taneda S, Kutty RK, Sayre LM, Monnier VM, Perry G (1994) Advanced Maillard reaction end products, free radicals, and protein oxidation in Alzheimer's disease. Ann N Y Acad Sci 738, 447-454.

[28] Smith MA, Perry G, Richey PL, Sayre LM, Anderson VE, Beal MF, Kowall N (1996) Oxidative damage in Alzheimer's. Nature 382, 120-121.

[29] Kadowaki H, Nishitoh H, Urano F, Sadamitsu C, Matsuzawa A, Takeda K, Masutani H, Yodoi J, Urano Y, Nagano T, Ichijo H (2005) Amyloid beta induces neuronal cell death through ROS-mediated ASK1 activation. Cell Death Differ 12, 19-24.

[30] Tabner BJ, El-Agnaf OM, Turnbull S, German MJ, Paleologou KE, Hayashi Y, Cooper LJ, Fullwood NJ, Allsop D (2005) Hydrogen peroxide is generated during the very early stages of aggregation of the amyloid peptides implicated in Alzheimer disease and familial British dementia. J Biol Chem 280, 35789-35792.

[31] Atamna H, Boyle K (2006) Amyloid-beta peptide binds with heme to form a peroxidase: Relationship to the cytopathologies of Alzheimer's disease. Proc Natl Acad Sci U S A 103, 3381-3386.

[32] Radak Z, Kumagai S, Taylor AW, Naito H, Goto S (2007) Effects of exercise on brain function: Role of free radicals. Appl Physiol Nutr Metab 32, 942-946.

[33] Kwon KJ, Kim HJ, Shin CY, Han SH (2010) Melatonin potentiates the neuroprotective properties of resveratrol against beta-amyloid-induced neurodegeneration by modulating AMP-activated protein kinase pathways. J Clin Neurol 6, 127-137.

[34] Li J, Dong Z, Liu B, Zhuo Y, Sun X, Yang Z, Ge J, Tan Z (2011) Hypoxia induces beta-amyloid in association with death of RGC-5 cells in culture. Biochem Biophys Res Commun 410, 40-44.

[35] Tillement L, Lecanu L, Papadopoulos V (2011) Alzheimer's disease: Effects of $\beta$-amyloid on mitochondria. Mitochondrion 11, 13-21.

[36] Cardoso SM, Swerdlow RH, Oliveira CR (2002) Induction of cytochrome c-mediated apoptosis by amyloid beta 25-35 requires functional mitochondria. Brain Res 931, 117-125.

[37] Yan SD, Xiong WC, Stern DM (2006) Mitochondrial amyloid-beta peptide: Pathogenesis or late-phase development? J Alzheimers Dis 9, 127-137.

[38] Newington JT, Pitts A, Chien A, Arseneault R, Schubert D, Cumming RC (2011) Amyloid beta resistance in nerve cell lines is mediated by the Warburg effect. PLoS One 6, e19191.
[39] Caspersen C, Wang N, Yao J, Sosunov A, Chen X, Lustbader JW, Xu HW, Stern D, McKhann G, Yan SD (2005) Mitochondrial Abeta: A potential focal point for neuronal metabolic dysfunction in Alzheimer's disease. FASEB J 19, 2040-2041.

[40] Barsoum MJ, Yuan H, Gerencser AA, Liot G, Kushnareva Y, Gräber S, Kovacs I, Lee WD, Waggoner J, Cui J, White AD, Bossy B, Martinou JC, Youle RJ, Lipton SA, Ellisman MH, Perkins GA, Bossy-Wetzel E (2006) Nitric oxideinduced mitochondrial fission is regulated by dynamin-related GTPases in neurons. EMBO J 25, 3900-3911.

[41] Veereshwarayya V, Kumar P, Rosen KM, Mestril R, Querfurth HW (2006) Differential effects of mitochondrial heat shock protein 60 and related molecular chaperones to prevent intracellular beta-amyloid-induced inhibition of complex IV and limit apoptosis. J Biol Chem 281, 29468-29478.

[42] Butterfield DA, Perluigi M, Sultana R (2006) Oxidative stress in Alzheimer's disease brain: New insights from redox proteomics. Eur J Pharmacol 545, 39-50.

[43] Ferreira IL, Resende R, Ferreiro E, Rego AC, Pereira CF (2010) Multiple defects in energy metabolism in Alzheimer's disease. Curr Drug Targets 11, 1193-1206.

[44] Lloret A, Badía MC, Mora NJ, Ortega A, Pallardó FV, Alonso MD, Atamna H, Viña J (2008) Gender and age-dependent differences in the mitochondrial apoptogenic pathway in Alzheimer's disease. Free Radic Biol Med 44, 2019-2025.

[45] Lloret A, Badia MC, Giraldo E, Ermak G, Alonso MD, Pallardo FV, Davies KJA, Viña J Alzheimer's amyloid- $\beta$ toxicity and tau hyperphosphorylation are linked via RCAN1. $J$ Alzheimers Dis 27, 701-709.

[46] Skulachev VP, Antonenko YN, Cherepanov DA, Chernyak BV, Izyumov DS, Khailova LS, Klishin SS, Korshunova GA, Lyamzaev KG, Pletjushkina OY, Roginsky VA, Rokitskaya TI, Severin FF, Severina II, Simonyan RA, Skulachev MV, Sumbatyan NV, Sukhanova EI, Tashlitsky VN, Trendeleva TA, Vyssokikh MY, Zvyagilskaya RA (2010) Prevention of cardiolipin oxidation and fatty acid cycling as two antioxidant mechanisms of cationic derivatives of plastoquinone (SkQs). Biochim Biophys Acta 1797, 878-889.

[47] Lott IT, Doran E, Nguyen VQ, Tournay A, Head E, Gillen DL (2011) Down syndrome and dementia: A randomized, controlled trial of antioxidant supplementation. Am J Med Genet A 155, 1939-1948.

[48] Skulachev VP (27) (2011) Mitochondria-targeted penetrating ions as inhibitors of the aging program and obesity. FEBS $J$ 278(Suppl.1) 39. 